\title{
Carrageenan as polymer matrix for selenium nanocomposites
}

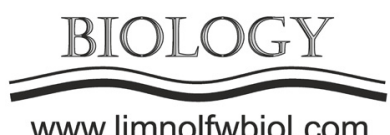

www.limnolfwbiol.com

\author{
Perfileva A.I. ${ }^{1 *}$, Nozhkina O.A. ${ }^{1}$, Graskova I.A. ${ }^{1}$, Sukhov B.G. ${ }^{2}$, Trofimov B.A. ${ }^{2}$ \\ ${ }^{1}$ Siberian Institute of Plant Physiology and Biochemistry SB RAS, Irkutsk, 664033 Russia \\ ${ }^{2}$ A.E. Favorsky Irkutsk Institute of Chemistry, SB RAS, Irkutsk, 664033 Russia
}

\begin{abstract}
Carrageenan derived from red algae has been used for the chemical synthesis of selenium nanocomposite (NC Se/Car), in which the content of selenium nanoparticles was $2 \%$. The effect of NC $\mathrm{Se} / \mathrm{Car}$ on the potato plants in vitro has been studied. The electron microscopy data have indicated that NC Se/Car comprises spherical selenium nanoparticles (of a wide size range) forming aggregates. Experiments in plants have shown a stimulating effect of NC Se/Car on plant biometric indicators and an effect of NC Se/Car decreasing harmful influence from Clavibacter sepedonicus (bacteria causing potato ring rot) infection. Some level of accumulation of selenium in potato tissues treated with NC $\mathrm{Se} / \mathrm{Car}(0.01-0.03 \%$ of air-dry weight) has been found. There is no negative effect of NC Se/Car on the viability of soil microorganisms. These results allow us to consider NC Se/Car as a plant growth stimulator for agricultural crops.
\end{abstract}

Keywords: carrageenan, selenium, potato plants, nanocomposite

\section{Introduction}

Carrageenan is a natural sulphated biopolymer extracted from red algae. This consists of alternating residues of 3-O-substituted- $\beta$-D-galactopyranose and 4-O-substituted $\quad 3,6$ anhydro- $\alpha$-D-galactopyranose. Carrageenan has various different biological activities: anticoagulating, antioxidant, antitumor, immunomodulating, and antiviral activity. Carrageenan is actively used in the food industry and medicine, however its biological properties are not fully characterized (Li et al., 2013; Tkachenko et al., 2016; Wang et al., 2016; Ermak et al., 2017; Błaszak et al., 2018; Groult et al., 2019).

Selenium is an important trace element for plants (White, 2018; Li et al., 2020). However, in recent years, it is often insufficient in soil, as well as in plants (Vihreva and Lebedeva, 2010; Aristarhov et al., 2018). In addition, the fertilizers used promote binding of selenium into insoluble and inaccessible forms for plants (Kiryushina, 2018). It is necessary to develop optimal preparations for the enrichment of plants with this element. For this purpose, a nanocomposite (NC) of selenium and carrageenan might may a potentially promising agent. The choice of carrageenan as a matrix is conditioned by its nature, since carrageenan is a soluble dietary fiber.

The purpose of this work was to study the effects of a carrageenan-based selenium nanocomposite (with
$2.0 \%$ selenium) on potato plants and safety of it's usage for the environment.

\section{Material and methods}

Synthesis of selenium and carrageenan nanocomposite. Carrageenan of WR-78 type (1800 $\mathrm{kDa}$ ) (Celko, Denmark) was used for synthesis of the nanocomposite. Water solution of $59 \mathrm{mg} / \mathrm{cm}^{3} \mathrm{SeO}_{2}$ and $0.1140 \mathrm{~g}$ of ascorbic acid was added under stirring to a solution of $5 \mathrm{~g}$ of carrageenan in $350 \mathrm{~mL}$ of water (Lesnichaya et al., 2019). One day later, the reaction mixture was precipitated in a fourfold volume of ethanol. The precipitate was filtered and dried at room temperature and atmospheric pressure. The yield was $94 \%$. The quantitative content of selenium in the sample determined via energy-dispersive X-ray spectroscopy microanalysis was $2.0 \%$. In the experiments, we used the NC solutions with $0.000625 \%$ selenium content.

Slightly alkaline water solution of NC was deposited onto formvar-coated grids and dried. The prepared samples were studied using a LEO 906E transmission electron microscope (Carl Zeiss, Germany) at an accelerating voltage of $80 \mathrm{kV}$. The microphotographs were taken with a MegaView II camera and processed using Mega Vision.

Cultivation of potato plants. The effect of NC on potato plants was studied using the Lukyanovsky cultivar. Clonal micropropagation of test-tube plants 
was carried out via cutting, on the agarized nutrient Murashige and Skoog medium. Plants were cultivated for 20 days at $26^{\circ} \mathrm{C}$ and light intensity of 5-6 klux.

For the experiment, an water solution of NC was added into the potato culture medium. In infected plants, a one-day bacterial suspension of Clavibacter sepedonicus ( $\mathrm{Cms}$ ) was added to the culture medium. Plants were incubated for 26 days, monitoring the biometric indicators every two days (plant length and quantity of leaves, length of internodes, weight of roots, and weight of aerial parts).

\section{Results and Discussion}

The resulting NC was orange and X-ray amorphous. The selenium nanoparticles (NPs) were visualized with a transmission electron microscope; they were predominantly spherical in shape, having a wide size distribution (30-150 nm, of $70 \mathrm{~nm}$ average size). Selenium NPs are capable of forming aggregates.

The biometric indicators of the plants were investigated. NC Se/Car stimulated plant growth rate within the entire observation period. The infection of plants with $\mathrm{Cms}$ after 10 days of coincubation resulted in a decline in plant growth rates. Carrageenan had no effect on the studied indicator. The Cms infection of plants combined with the NC Se/Car treatment made no difference compared to the control within up to 10 days, however, afterwards, this resulted in a decline in plant growth rates. At the same time, treatment with NC Se/Car did not affect bacteria spread throughout the plant. Bacteria were found in roots, stems, leaves, and internodes of potato plants. The infected potato plants had fewer leaves than the control. The treatment of potatoes with carrageenan did not affect the number of leaves compared to the control. NC Se/Car significantly increased the number of leaves in potatoes compared to the control. The NC Se/Car treatment combined with $\mathrm{Cms}$ infection of plants reduced the number of leaves in plants compared to the control, and compared to bacterial infection. No "elongation effect" on plants was observed upon treatment with $\mathrm{NC}$ and during the combined action of NC and Cms. At the end of the experiment, the biomass of the plant aerial parts and roots was determined. The Cms infection of plants, without and combined with NC Se/Car treatment, significantly reduced the mass of roots and of the vegetative region of plants. Carrageenan did not affect the biomass of the aerial regions and roots of plants. The largest mass of roots and of the green region of plants were found in potato treatment with NC Se/Car.

At the next stage of our studies, we checked whether selenium would be accumulated in the potato tissues after the treatment with NC Se/Car. Results of energy-dispersive X-ray spectroscopy microanalysis of potato plant tissues, that selenium was not found in the check plants. Selenium was detected only in plants treated with NC Se/Car $(0.03 \%$ selenium content of plant air-dry weight) and in the Cms-infected plants treated with NC Se/Car $(0.01 \%$ selenium content of plant airdry weight).
We studied the influence of NC Se/Car on the viability of rhizospheric microorganisms Acinetobacter guillouiae and Rhodococcus erythropolis. Such microorganisms have been chosen by us because they live not only in the rhizosphere of plants, but also in the soil. The presence of bactericidal and anti-biofilm effects of NC Se/Car on the rhizospheric bacteria under study was also investigated. As a result of the experiments carried out, no negative effects of NC Se/Car on the viability of bacteria and their biofilm formation were revealed.

\section{Conclusions}

The results of this study demonstrate the positive effect of NC Se/Car on potato plants. It is shown that selenium does not accumulate practically in potato tissues after their treatment with a composite. There is no negative impact of NC Se/Car on the viability of rhizospheric bacteria. This nanocomposite may be applied as a plant growth and development stimulator, and, at the same time, no substantia accumulation of selenium takes place in potato tissues.

This work was partly financially supported by a President of Russia grant for young scientists No. MK-1220.2019.11.

\section{Reference}

Aristarhov A.N., Busygin A.S., Yakovleva T.A. 2018. Deficit Selenium deficiency in the soils and plants of northeastern Nechernozem'ya as an indicator of the need for selenium fertilizers. Mezhdunarodnyj Sel'skohozyajstvennyj Zhurnal [International Agricultural Journal] 361: 31-37. DOI: 10.24411/2587-6740-2018-11008 (in Russian)

Błaszak B.B., Gozdecka G., Shyichuk A. 2018. Carrageenan as a functional additive in the production of cheese and cheeselike products. Acta Scientiarum Polonorum, Technologia Alimentaria 17: 107-116. DOI: 10.17306/J.AFS.0550

Ermak I.M., Mishchenko N.P., Davydova V.N. et al. 2017. Polisaharidy krasnyh vodoroslej kak osnova dlya dostavki lekarstvennogo preparata gistrohrom. In: All-Russian Conference "Chemistry and Technology of Plant Substances", pp. 6-7. (in Russian)

Groult H., Cousin R., Chot-Plassot C. et al. 2019. $\lambda$-Carrageenan oligosaccharides of distinct anti-heparanase and anticoagulant activities inhibit MDA-MB-231 breast cancer cell migration. Marine Drugs 17. DOI: 10.3390/ md17030140

Kiryushina A.P. 2018. Relevance and environmental risks of selenium fertilizer use. Ispol'zovanie i Ohrana Prirodnyh Resursov v Rossii [Use and Protection of Natural Resources in Russia] 154: 33-35. (in Russian)

Lesnichaya M.V., Shendrik R., Sukhov B.G. 2019. Relation between excitation dependent luminescence and particle size distributions for the selenium nanoparticles in $\square$-carrageenan shell. Journal of Luminescence 211: 305-313. DOI: 10.1016/j. jlumin.2019.03.056

Li B., Zaveri T., Ziegler G.R. et al. 2013. User preferences in a carrageenan-based vaginal drug delivery system. PLoS One 8. DOI: 10.1371/journal.pone.0054975

Li Y., Zhu N., Liang X. et al. 2020. A comparative study on the accumulation, translocation and transformation of selenite, selenate, and SeNPs in a hydroponic-plant system. Ecotoxicology and Environmental Safety 189. DOI: $10.1016 /$ j. ecoenv.2019.109955 
Tkachenko A.S., Zhukov V.I, Gubina-Vakulik G.I. et al. 2016. Vliyanie dlitel'nogo peroral'nogo upotrebleniya pishchevoj dobavki karraginan na urovne karbonilirovannyh belkov v syvorotke krovi krys. Vestnik Problem Biologii i Mediciny [The Bulletin of Problems of Biology and Medicine] 1: 133. (in Russian)

Vihreva V.A., Lebedeva T.B. 2010. Selenium content in soils and forest steppe plants in the middle Volga region. Molodoj Uchenyj [Young Scientist] 22: 195-198. (in Russian)

Wang F., Tong Q., Luo J. et al. 2016. Effect of carrageenan on physicochemical and functional properties of low-fat colby cheese. Journal of Food Science 81: 1949-1955. DOI: 10.1111/1750-3841.13369

White P.J. 2018. Selenium metabolism in plants. Biochimica et Biophysica Acta: General Subjects 4165: 3013830147. DOI: 10.1016/j.bbagen.2018.05.006 